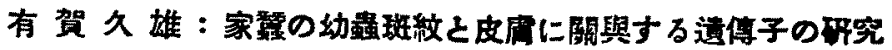

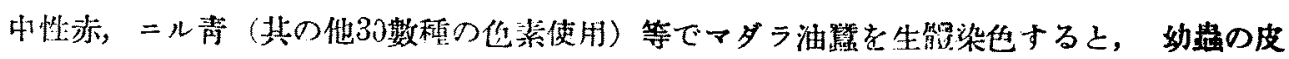

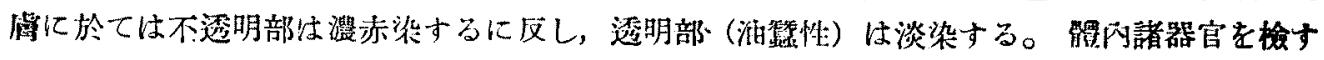

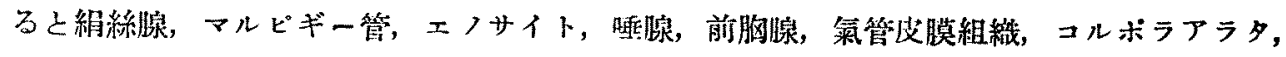

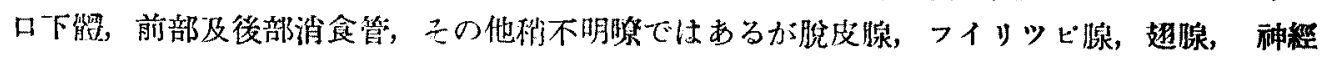

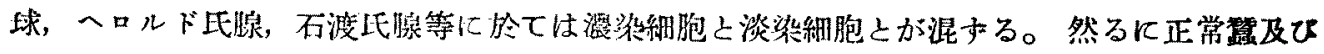

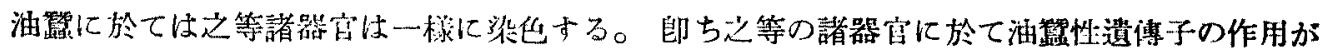

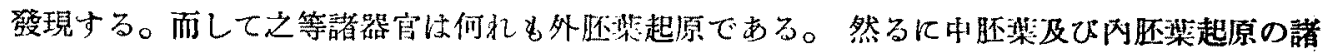

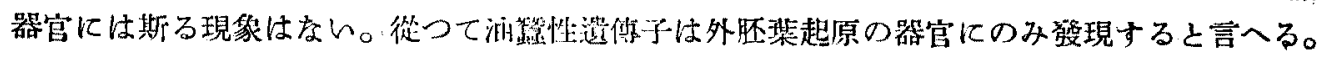

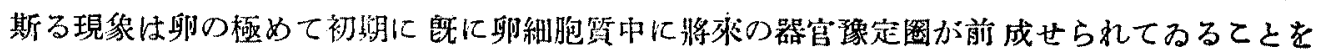
暗示する。

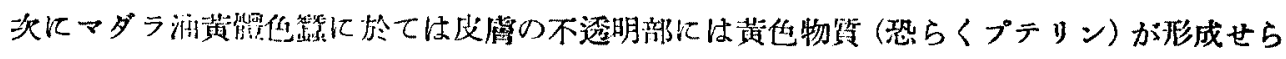

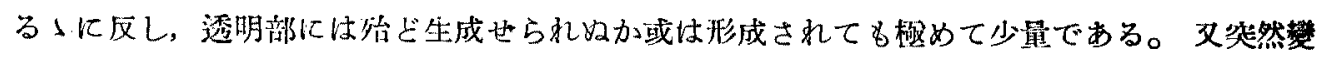

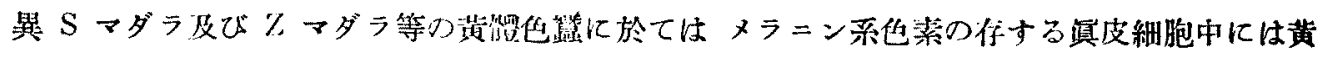

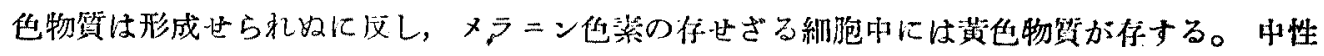

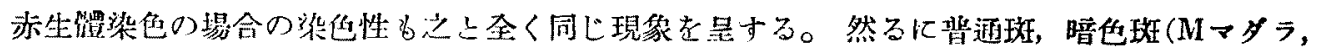

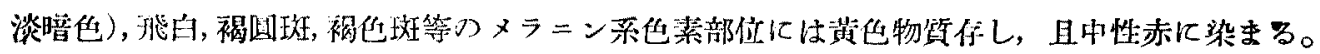

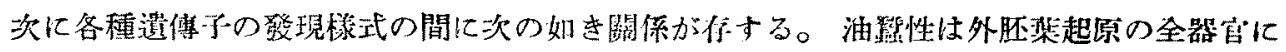

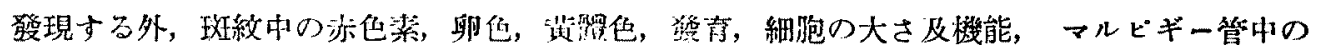

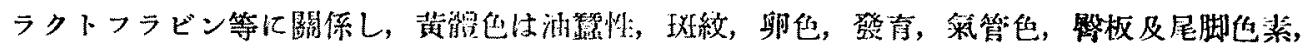

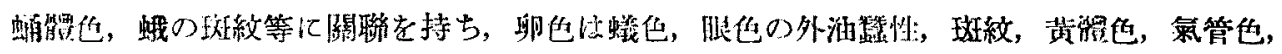

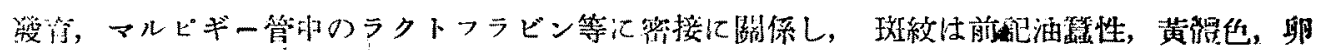

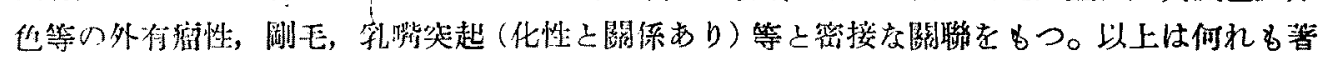

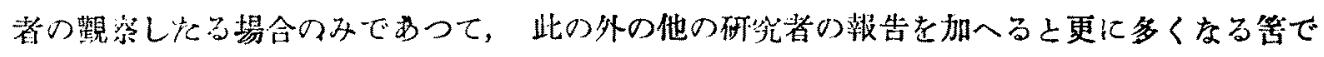
ある。

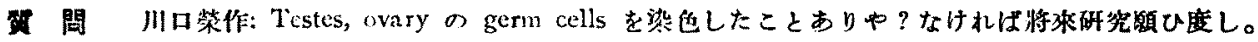

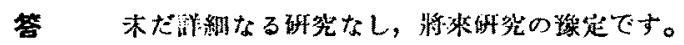

\section{古畑種基：Rh 因子の遺傅に就}

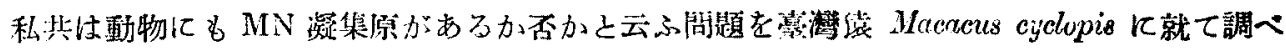

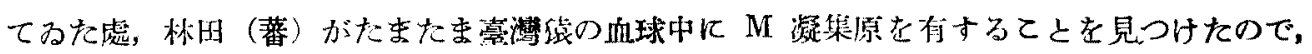

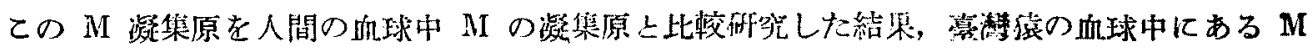

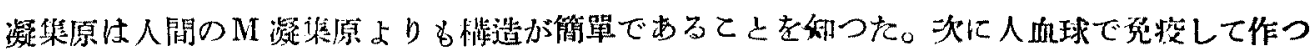

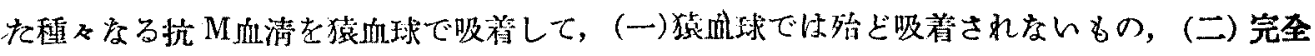
に吸着されるもの，(三)一部分吸着されるもの，(四）或るM血球には尚反應するが或る M 血球には全然反㕍しなくをるものの四型に區別することが出隶た。この四種の抗 M 血清を 